\title{
Pelatihan Myob Accounting pada UKM Mahasiswa Akuntansi AMIK Indonesia
}

\author{
Rusman ${ }^{1}$, Saluddin Al Cassany ${ }^{2 *}$, Nurhayati ${ }^{3}$ \\ 1,3 Program Studi Akuntansi, Fakultas Ekonomi, Sekolah Tinggi Ilmu Ekonomi Sabang, Jalan \\ Peurada Utama Po Box 166, Kota Banda Aceh, Provinsi Aceh, Indonesia. \\ 2 Program Studi Manajemen, Fakultas Ekonomi, Sekolah Tinggi Ilmu Ekonomi Sabang, Jalan \\ Peurada Utama Po Box 166, Kota Banda Aceh, Provinsi Aceh, Indonesia \\ Corresponding Email: saluddinalcassany@stiesabang.ac.id 22.
}

\author{
Article History: \\ Received: Jan 12th 2021 \\ Revised: Feb 3th 2021 \\ Accepted: Apr 23th 2021 \\ Keywords: Training; Myob \\ Accounting; Student Activity \\ Units; Accounting.
}

\begin{abstract}
A student activity unit is a place for students to develop the talents, interests, expertise of each student, and the ability to socialize with the outside world. So, a high GPA will not guarantee that students will get success. However, the social skills that have been obtained in participating in UKM are the most valuable thing and at the same time are the key to the success of students in facing the outside world. MYOB accounting is an accounting software required by companies that are integrated (integrated software). In detail, the problem to be solved in this Community Service activity is whether through this training will be able to improve the ability of accounting SMEs in running Myob? This community service activity is intended for SMEs to overcome their obstacles in preparing company financial reports. Activities that have been carried out are in the form of training on the use of accounting system simulation tools for SMEs with as many as 20 participants from UKM. The next activity is the implementation of simulation tools and mentoring activities are carried out. The evaluation results conclude that the Utilization Index of the tools assessed by UKM managers which are calculated using the usefulness index results in a range of IKP values of 89 in the range $b+4 c \leq I K P<a$. IKP is at this interval, which means that UKM managers state that accounting simulation tools are very useful to be applied in UKM.
\end{abstract}




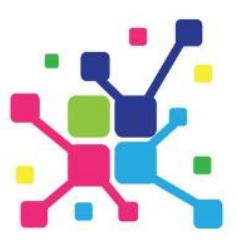

\section{Pendahuluan}

Banyak mahasiswa yang menganggap jika nilai akademik/ IPK tinggi akan menjamin keberhasilan mahasiswa dikemudian hari $[1,2]$. Perlu diperhatikan bahwa nilai akademik / IPK (indeks prestasi komulatif) bukan satu-satunya yang menjadi tolak ukur keberhasilan mahasiswa [3, 4]. Banyak mahasiswa yang lebih mementingkan nilai IPK tinggi daripada bagaimana cara penerapan pengetahuan yang mereka miliki dalam kehidupan nyata [5, 6]. Jadi, IPK tinggi tidak ada manfaatnya apabila mahasiswa tersebut tidak memiliki pengalaman atau kemampuan dibidangnya dan juga tidak memiliki pengalaman untuk bersosialisasi dengan dunia luar $[7,8]$. Contohnya sebuah perusahaan tidak akan menerima karyawan walaupun nilai IPK nya tinggi tetapi ia kurang berpengalaman, kurang bersosialisasi dengan orang lain apalagi ia memiliki etika yang buruk. Unit kegiatan mahasiswa merupakan tempat mahasiswa untuk mengembangkan bakat, minat, keahlian dari masing-masing mahasiswa, dan kemampuan untuk bersosialisasi dengan dunia luar $[9,10]$. Jadi, IPK tinggi tidak akan menjamin bahwa mahasiswa akan memperoleh keberhasilan $[8,11]$. Tapi, kemampuan bersosialisasi yang telah didapatkan dalam mengikuti UKM adalah hal yang paling berharga dan sekaligus sebagai kunci keberhasilan mahasiswa dalam menghadapi dunia luar [12, 13, 14].

MYOB accounting adalah sebuah software akuntansi yang diperlukan oleh perusahaan yang dibuat secara terpadu (integrated software) [15, 16]. MYOB Accounting dikembangkan pertama kali oleh Limited Australia dan sekarang sudah dikembangkan di beberapa negara lain seperti Amerika, Kanada, Selandia Baru, dan lain-lain [17, 18, 19]. Beberapa kelebihan MYOB Accounting adalah sebagai berikut :

1) Mudah digunakan

2) Tingkat keamanan yang cukup valid

3) Kemampuan explorasi ke program excel lebih mudah

4) Kemampuan trash back semua laporan ke source dokumen dan source transaksi

5) Dapat diaplikasikan untuk 105 jenis perusahaan

6) Menampilkan laporan keuangan dengan komparasi

7) Software tersebut telah teruji $[18,19]$.

Para peserta UKM akuntansi diberi pelatihan agar bisa menggunakan Myob Accounting untuk memberikan kemampuan individual sehingga dapat terjun kedunia kerja. Tujuan kegiatan PPM ini adalah untuk meningkatkan kemampuan para peserta UKM akuntansi AMIK Indonesia. Manfaat Pengabdian Kepada Masyarakat adalah bagi para peserta UKM akuntansi AMIK Indonesia yang diselenggarakan di Sekolah Tinggi Ilmu Ekonomi Sabang (STIES) pelatihan ini diharapkan akan dapat menyusun laporan keuangan yang berupa neraca, perhitungan laba rugi, dan laporan arus kas kedalam Myob 


\section{Metode}

a. Metode Pelaksanaan Kegiatan

Pelaksanaan kegiatan Pengabdian Pada Masyarakat ini dilakukan dengan menggunakan metode ceramah, tutorial, dan diskusi. Dimana penggunaan metode tersebut sangat aktif digunakan pada kegiatan pengabdian [20, 21]. Adapun sistematika pelaksanaan kegiatan pengabdian ini adalah sebagai berikut:

1) Langkah 1 (Metode Ceramah):

Peserta diberikan motivasi agar memiliki kemauan untuk menggunakan akuntansi dalam kegiatan bisnisnya. Selain itu, peserta diberikan materi gambaran umum tentang Myob akuntansi dan peran penting akuntansi bagi perusahaan. Langkah pertama diselenggarakan selama 1 jam.

2) Langkah 2 (Metode Tutorial):

Peserta pelatihan diberikan materi Myob akuntansi mulai dari pencatatan sampai dengan menyusun laporan keuangan. Langkah kedua diselenggarakan selama 5 jam.

3) Langkah 3 (Metode Diskusi):

Peserta pelatihan diberikan kesempatan untuk mendiskusikan permasalahan yang berkaitan dengan keuangan UMKM yang selama ini dihadapi. Langkah ketiga diselenggarakan selama 1 jam.

Dalam tahap persiapan ini yang dilakukan adalah; 1) Penyiapan berbagai adiministrasi yang mungkin diperlukan, 2) koordinasi dengan UKM AMIK Indonesia Banda Aceh, 3) Penyiapan materi pelatihan tentang Myob Accounting, 4) Penyiapan Nara Sumber yang kompeten dan relevan dengan materi yang disiapkan, dan 5) Penyiapan Jadwal pelatihan selama 4 hari efektif. Pada tahapan ini kegiatan yang dilakukan adalah Pelatihan Menggunaan Myob. Sedangkan pada Tahap monitoring kegiatan yang dilakukan adalah pengawasan/ monitoring terhadap implementasi kegiatan yang berhubungan dengan Myob

b. Waktu Efektif Pelaksanaan Kegiatan

Kegiatan Pelaksanaan Pengabdian Kepada Masyarakat ini dilakukan selama 1(satu) bulan pada bulan Juni 2014.

c. Tempat Kegiatan

Lokasi pengabdian ini pada UKM Akuntansi AMIK Indonesia. Pelatihan ini difokuskan kepada UKM akuntansi di AMIK Indonesia Banda Aceh sebanyak 20 peserta. 

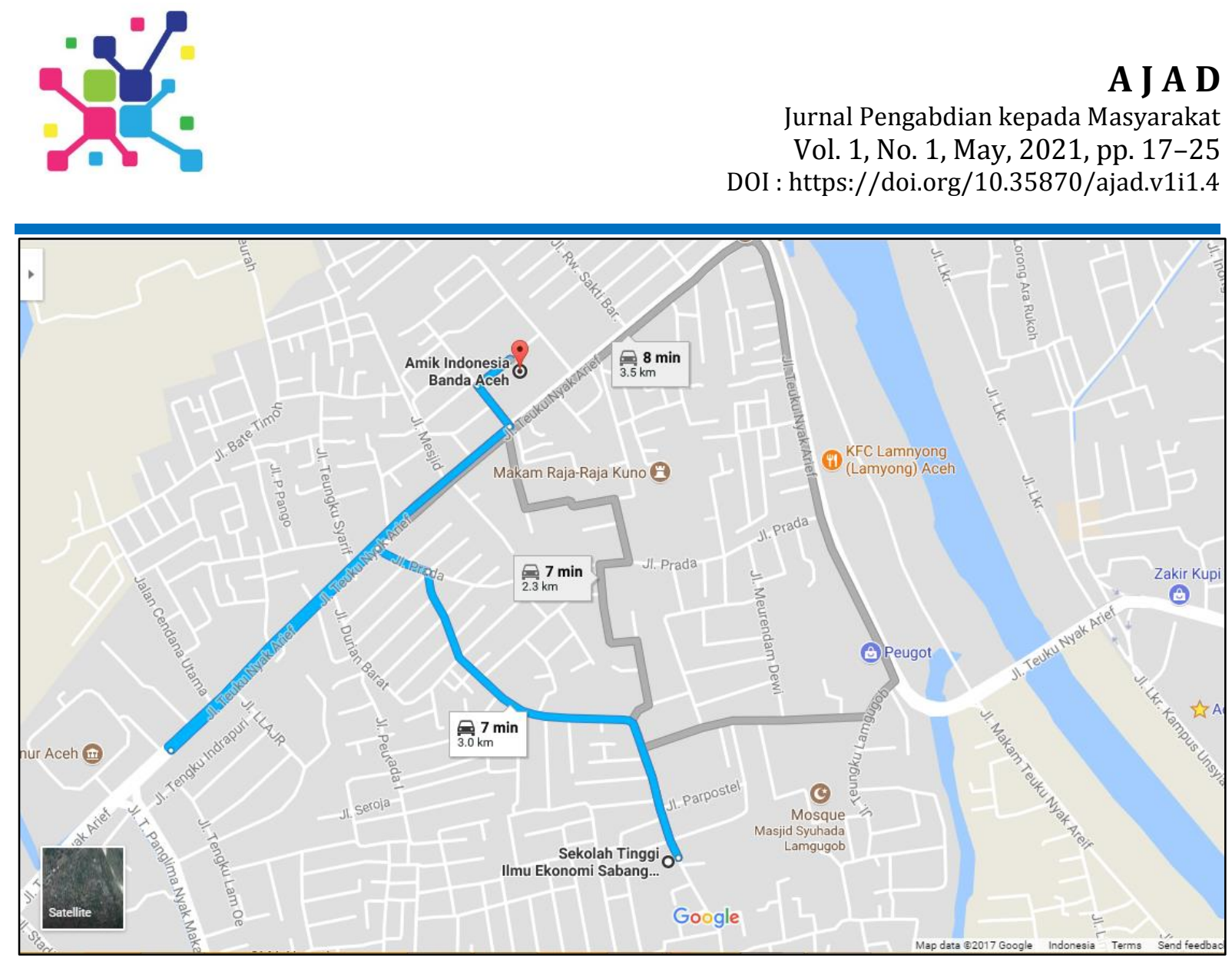

Gambar 1. Map Lokasi Kegiatan

\section{Hasil}

a. Hasil Pelaksanaan Kegiatan

Kegiatan pengabdian ini terselenggara atas kerjasama dengan UKM Akuntansi AMIK Indonesia. Kegiatan pelatihan ini merupakan salah satu tahapan penting dari kegiatan pengabdian kepada masyarakat sebagai bagian Tridarma Perguruan Tinggi yang dilaksanakan pada bulan Juni 2014 mulai jam 14.00 WIB hingga selesai. Pelatihan dilakukan di Laboratorium Komputer AMIK Indonesia Banda Aceh. Yang memberi kata sambutan dalam pelatihan ini adalah Direktur AMIK Indonesia Banda Aceh. Sedangkan sebagai narasumber kegiatan penyuluhan ini adalah dosen Sekolah Tinggi Ilmu Ekonomi Sabang (STIES). Selain memberikan ceramah pada pelatihan tersebut, narasumber juga membagikan brosur usaha ekonomi kreatif. Kegiatan berlangsung lancar dengan suasana kenyamanan yang sangat kental.

Peserta yang hadir dalam pelatihan ini adalah sejumlah 20 orang peserta yaitu dari UKM Akuntansi AMIK Indonesia Banda Aceh. Materi yang disiapkan pada pelatihan ini meliputi proses penyusunan laporan keuangan kedalam myob yaitu; pembuatan jurnal, buku besar, laporan neraca, laporan Sisa Hasil Usaha, dan laporan arus kas. Materi tersebut disiapkan dalam bentuk Powerpoint, dan dalam bentuk soal-soal kasus pada perusahaan. Pemberian materi pelatihan ini berlangsung selama 4 jam. Materi yang disampaikan antara lain penyusunan jurnal, posting jurnal ke Buku Besar, Laporan Sisa Hasil Usaha, Neraca dan Laporan arus kas ke dalam Myob 
b. Pembahasan Hasil Pelaksanaan Kegiatan Pengabdian

Kebermanfaatan pemanfaatan perangkat myob akuntansi pada kegiatan pengabdian kepada masyarakat ini di evaluasi dengan cara menyebarkan Kuisioner kepada pihak UKM mengenai persepsi mereka terhadap efektivitas perangkat simulasi. Daftar pertanyaan tersebut dikelompokkan kedalam 4 dimensi yaitu : (a) Bukti langsung (tangible) yaitu berupa penampakkan fisik yang meliputi sistematika penyajian, format-format, warna, dan kondisi fisik tentang myob.; (b) keandalan (reability) yaitu terkait dengan substansi perangkat di dalam menyajikan materi yang sesuai dengan substansi keilmuan dan kondisi riil di dunia kerja (UKM); (c) daya tanggap (responsiveness) yaitu kesediaan, kesiapan dan kemampuan perangkat di dalam memberikan informasi / kemudahan memahami maksud yang terkandung di dalam perangkat; (d) jaminan (assurance) menyangkut jaminan atas keaslian materi dalam perangkat ajar serta jaminan atas materi yang terkandung up to date).

Berdasarkan hasil kuisioner yang disebarkan maka dapat dibahas beberapa hal sebagai berikut :

1) Pada dimensi bukti langsung (tangiable) menunjukkan 48\% peserta UKM menyatakan sistematika penyajian perangkat simulasi akuntansi sangat bermanfaat, $42 \%$ menyatakan bermanfaat dan sisanya sebanyak $10 \%$ menyatakan kurang bermanfaat. Dalam hal penyajian format perangkat simulasi akuntansi $36 \%$ menyatakan sangat bermanfaat, $42 \%$ menyatakan bermanfaat dan sisanya $22 \%$ menyatakan bermanfaat. Untuk dimensi perangkat simulasi sebanyak 66\% peserta UKM menyatakan sangat bermanfaat dan $34 \%$ menyatakan bermanfaat. Sedangkan untuk kondisi fisik perangkat simulasi akuntansi secara keseluruhan $72 \%$ menyatakan sangat bermanfaat dan sisanya $28 \%$ menyatakan bermanfaat.

2) Berdasarkan hasil kuisioner tersebut menunjukkan bahwa berdasarkan bukti langsung skor rata-rata berada pada rentang nilai 88 ini menunjukkan secara umum peserta UKM sepakat bahwa perangkat simulasi dapat digunakan di UKM. Pada dimensi keandalan (reliability) menunjukkan untuk relevansi isi dengan kondisi kerja sebanyak $36 \%$ pengelola UKM menyatakan sangat bermanfaat dan sisanya sebanyak $64 \%$ menyatakan bermanfaat. Untuk format-format bukti transaksi sebanyak $28 \%$ menyatakan sangat bermanfaat, $60 \%$ menyatakan bermanfaat namun ada sebanyak $12 \%$ yang menyatakan kurang bermanfaat. Untuk format-format jurnal sebanyak $66 \%$ menyatakan sangat bermanfaat, 34 $\%$ menyatakan bermanfaat. Sedangkan untuk format kertas kerja lainnya sebanyak 56\% menyatakan sangat bermanfaat, $38 \%$ menyatakan bermanfaat namun ada $6 \%$ yang menyatakan kurang bermanfaat. Terkait materi yang tersaji terutama untuk perusahaan jasa sebanyak $64 \%$ menyatakan sangat bermanfaat, $36 \%$ menyatakan bermanfaat. Sedangkan terkait untuk materi perusahaan dagang sebanyak $70 \%$ menyatakan sangat bermanfaat, $26 \%$ menyatakan 
bermanfaat namun ada juga sebesar 4\% yang menyatakan kurang bermanfaat. Sedangkan untuk materi yang terkandung di bidang usaha manufaktur sebanyak $38 \%$ menyatakan sangat bermanfaat, $56 \%$ menyatakan bermanfaat dan sebesar $6 \%$ menyatakan kurang bermanfaat. Berdasarkan hasil kuisioner tersebut menunjukkan bahwa berdasarkan keandalan skor rata-rata berada pada rentang nilai 88 ini menunjukkan secara umum pengelola UKM sepakat bahwa perangkat simulasi akuntansi bermanfaat digunakan di UKM.

3) Dimensi daya tanggap (responsiviness) menunjukkan untuk kesesuaian isi materi perangkat simulasi akuntansi dengan kondisi kerja terkini adalah sebanyak $76 \%$ pengelola UKM menyatakan sangat bermanfaat, sebanyak $20 \%$ menyatakan bermanfaat dan ada sebanyak $4 \%$ menyatakan kurang bermanfaat. Sedangkan daya tanggap perangkat simulasi akuntansi akan pemanfaatan perkembangan teknologi pengelola UKM sependapat sangat bermanfaat dengan $86 \%$ berada pada kelompok ini walaupun ada sebanyak $14 \%$ yang menyatakan bermanfaat. Sedangkan terkait dengan kepraktisan dalam kemudahan memahami isi sebanyak $50 \%$ menyatakan sangat bermanfaat, $44 \%$ menyatakan bermanfaat namun ada juga sebesar $6 \%$ yang menyatakan kurang bermanfaat. Sedangkan terkait dengan kemudahan dalam memahami instruksi kerja pada perangkat simulasi akuntansi sebanyak 34\% menyatakan sangat bermanfaat, 54 $\%$ menyatakan bermanfaat namun ada juga sebesar $12 \%$ yang menyatakan kurang bermanfaat. Berdasarkan hasil kuisioner tersebut menunjukkan bahwa berdasarkan daya tanggap skor rata-rata berada pada rentang nilai 86 ini menunjukkan secara umum pengelola UKM sepakat bahwa perangkat simulasi akuntansi bermanfaat digunakan di UKM.

4) Pada dimensi jaminan (assurance) menunjukkan untuk keaslian isi dalam hal belum pernah melihat atau menggunakan perangkat seperti perangkat simulasi akuntansi sebanyak $42 \%$ pengelola UKM menyatakan sangat bermanfaat, dan sebanyak 68\% menyatakan bermanfaat. terkait dengan jaminan kesesuaian dengan Standar Akuntansi Keuangan, Untuk kesesuaian dengan standar akuntansi terkait dengan penyajian laporan keuangan sebanyak $68 \%$ menyatakan sangat bermanfaat dan sisanya $32 \%$ menyatakan bermanfaat. Untuk kesesuaian dengan penyajian aktiva lancar dan kewajiban jangka pendek sebanyak $54 \%$ menyatakan sangat bermanfaat dan sisanya $46 \%$ menyatakan bermanfaat. Untuk kesesuaian dengan penyajian persediaan sebanyak $86 \%$ menyatakan sangat bermanfaat dan sisanya $14 \%$ menyatakan bermanfaat. Untuk kesesuaian dengan penyajian asset tetap sebanyak $72 \%$ menyatakan sangat bermanfaat dan sisanya $28 \%$ menyatakan bermanfaat. Untuk kesesuaian dengan akuntansi penyusutan sebanyak $74 \%$ menyatakan sangat bermanfaat dan sisanya $26 \%$ menyatakan bermanfaat. Untuk kesesuaian dengan akuntansi ekuitas sebanyak $58 \%$ menyatakan sangat bermanfaat dan sisanya $42 \%$ menyatakan bermanfaat. Untuk kesesuaian dengan pendapatan sebanyak $84 \%$ 
menyatakan sangat bermanfaat dan sisanya $16 \%$ menyatakan bermanfaat. Sedangkan yang terakhir untuk kesesuaian dengan laba bersih untuk periode berjalan sebanyak $58 \%$ menyatakan sangat bermanfaat dan sisanya $42 \%$ menyatakan bermanfaat. Berdasarkan hasil kuisioner tersebut menunjukkan bahwa berdasarkan jaminan skor rata-rata berada pada rentang nilai 92 ini menunjukkan secara umum pengelola UKM sepakat bahwa peragkat simulasi sangat bermanfaat digunakan di UKM.

5) Sedangkan untuk Indeks Kebermanfaatan Pengelola UKM Akuntansi yang dihitung dengan indek kepuasan para pengelola UKM menghasilkan rentang nilai IKP senilai 89 berada pada rentang $b+4 c$ IKP $<$ a. IKP berada pada interval ini berarti pengelola UKM menyatakan bahwa perangkat simulasi akuntansi sangat bermanfaat untuk diaplikasikan di UKM.

\section{Kesimpulan}

Kegiatan pengabdian kepada masyarakat ini ditujukan bagi UKM untuk mengatasi kendala mereka dalam hal menyiapkan laporan keuangan perusahaan. Kegiatan yang sudah dilaksanakan berupa kegiatan pelatihan pemanfaatan perangkat simulasi sistem akuntansi bagi UKM dengan peserta sebanyak 20 dari UKM. Kegiatan berikutnya berupa implementasi perangkat simulasi dan dilakukan kegiatan pendampingan.

Kebermanfaatan kegiatan pengabdian masyarakat ini dievaluasi melalui kuisioner dengan pengujian kebermanfaatan perangkat simulasi yang dihitung perspektif pengelola UKM yang dijabarkan kedalam empat dimensi kualitas yaitu : (a) Bukti langsung (tangible) yaitu berupa penampakkan fisik perangkat, (b) keandalan (reability) yaitu terkait dengan substansi perangkat, (c) daya tanggap (responsiveness) yaitu kesediaan, kesiapan dan kemampuan perangkat di dalam memberikan informasi / kemudahan memahami maksud yang terkandung di dalam perangkat, (d) jaminan (assurance) menyangkut jaminan atas keaslian materi dalam perangkat serta jaminan atas materi yang terkandung up to date dan sesuai dengan pedoman Standar Akuntansi Keuangan (SAK). Hasil evaluasi menyimpulkan bahwa Indeks Kebermanfaatan perangkat yang dinilai oleh pengelola UKM yang dihitung dengan indek kebermanfaatan menghasilkan rentang nilai IKP senilai 89 berada pada rentang $b+4 c$ 国国 $\mathrm{KP}<\mathrm{a}$. IKP berada pada interval ini berarti pengelola UKM menyatakan bahwa perangkat simulasi akuntansi sangat bermanfaat untuk diaplikasikan di UKM. 


\section{Daftar Referensi}

[1] Aswitami, A.P., 2014. Perbedaan Kualitas Soft skill Mahasiswa Sebelum dan Sesudah Pelatihan Manajemen Diri. Jurnal Dunia Kesehatan, 5(2), p.76844.

[2] Hernawati, E., Idjradinata, P.S., Husen, I.R., Husin, F., Wirakusumah, F.F., Shahib, M.N. and Herawati, D.M., 2015. Perbedaan Kualitas Soft Skill Mahasiswa Sebelum dan Sesudah Pelatihan Manajemen Diri.Jurnal Pendidikan dan Pelayanan Kebidanan Indonesia, 2(2), pp.50-56.

[3] Fahrurrozi, F., 2017. Perbandingan indeks prestasi komulatif (IPK) mahasiswa program bidikmisi dengan mahasiswa non bidikmisi jurusan pendidikan IPS Ekonomi Fakultas Tarbiyah dan Keguruan (FTK) Universitas Islam Negeri (UIN) Mataram Tahun Akademik 2017/2018 (Doctoral dissertation, UIN Mataram).

[4] Komalasari, H. and Irawan, A.T., 2018. Hubungan Motivasi Menjadi Perawat dengan Prestasi Akademik Mahasiswa Akper YPIB Majalengka Tahun 2017. Jurnal Keperawatan dan Kesehatan MEDISINA AKPER YPIB, pp.1-10.

[5] Oviyanti, F., 2016. Tantangan pengembangan pendidikan keguruan di era global. Nadwa, 7(2), pp.267-282.

[6] Ahmad, L., Sufyan, S. and Ahmad, A., 2020. Pelatihan Penggunaan Software Content Admission Sebagai Implementasi dari Konsep Complement Online Learning pada AMIK Indonesia. Jurnal Pengabdian Nasional (JPN) Indonesia, 1(2), pp.41-46.

[7] Ratnasari, N., 2020. PERSEPSI MAHASISWA TERHADAP URGENSI UNIT KEGIATAN MAHASISWA (UKM) UKI ULIN NUHA SEBAGAI PUSAT KEGIATAN KEAGAMAAN DI IAIN PONOROGO (Doctoral dissertation, IAIN Ponorogo).

[8] Masruroh, A., 2013. Praktik Budaya Akademik Mahasiswa. Paradigma, 1(2).

[9] Farida, S.I. and Khair, O.I., 2019. Leadership sebagai Dasar Kecerdasan Intelektual Mahasiswa Program Studi Manajemen di Universitas Pamulang. JIMF (Jurnal Ilmiah Manajemen Forkamma), 3(1).

[10] Azazi, A., 2018. Perbedaan Aktualisasi Diri Pada Mahasiswa Yang Mengikuti Organisasi Dengan Mahasiswa Yang Tidak Mengikuti Organisasi (Doctoral dissertation, Ilmu Psikologi).

[11] Farida, S.I. and Anjani, S.R., 2019. Menumbuhkan jiwa kepemimpinan pada mahasiswa di lingkungan Universitas Pamulang. Inovasi, 6(2), pp.19-20. 
[12] Sufyan, S. and Ahmad, L., 2020. Pelatihan Penyusunan Rencana Pembangunan Jangka Menengah Gampong (RPJMG) berbasis Masyarakat di Gampong Alue Naga Kecamatan Syiah Kuala Kota Banda Aceh. Jurnal Pengabdian Nasional (JPN) Indonesia, 1(2), pp.51-55.

[13] Murtiningsih, M., 2020. Penyuluhan Kesehatan Pola Hidup Sehat Secara Daring menggunakan Zoom dan Youtube Sebagai Media Ajar pada Masa Pandemi COVID19. Jurnal Pengabdian Nasional (JPN) Indonesia, 1(2), pp.37-40.

[14] Ahmad, L., Wali, M., Akbar, R. and Syafwandhinata, J., 2020. IbM Pemberdayaan Generasi Muda melalui Enterpreneurship.Jurnal Pengabdian Nasional (JPN) Indonesia, 1(1), pp.30-36.

[15] Zeinora, Z., 2020. Analisis Kelebihan Dan Kekurangan Serta Kebermanfaatan Menggunakan Software Accurate, Myob, Zahir Accounting Dan Penerapannya Di Universitas Indraprasta PGRI.JABE Uournal of Applied Business and Economic), 6(4), pp.341-353.

[16] Rizal, S., Wali, M., 2018. Perbankan Komputer : Teori dan Praktikum. Deepublish.

[17] Riyadi, S. and Apriana, V., 2019. PENERAPAN APLIKASI MYOB UNTUK PENGOLAHAN DATA AKUNTANSI STUDI KASUS: PT. QUANTUM ELECTRINDO LESTARI. Jurnal Mantik Penusa, 3(2, Des).

[18] Mahmudi, A., 2009. MYOB-Accounting Premier. Grasindo.

[19] Ahmad, A. and Sholeh, B., 2018. MYOB Accounting 24. Deepublish.

[20] Marwang, S. and Sudirman, J., 2020. Upaya Peningkatan Pengetahuan Tentang Pencegahan Covid-19 dengan Perilaku Hidup Bersih, Sehat dan Gizi Seimbang di Panti Asuhan. Jurnal Pengabdian Nasional (JPN) Indonesia, 1(2), pp.47-50.

[21] Idawati, I., Yuliana, Y., Rosalinda, M. and Kartini, K., 2020. Penyuluhan Kesehatan Tentang Pentingnya Program Keluarga Berencana di Desa Balee Ujong Rimba Kecamatan Mutiara Timur Kabupaten Pidie. Jurnal Pengabdian Nasional (JPN) Indonesia, 1(2), pp.56-62. 